\title{
Pig progeny testing stations : performance from 1953 to 1982
}

\author{
M. MOLENAT *, K.T. NGUYEN** \\ * I.N.R.A., Station de Génétique quantitative et appliquése \\ Domaine de Vilvert, 78350 Jouy-en-Josas \\ France \\ ** Stagiaire de l'Ecole d'Agriculture n" I d'Hanö \\ Vietnam
}

Station testing for growth and carcass traits has been carried out on pigs from selection herds for more than thirty years. Results obtained may be summarized as follows :

- from 1953 to 1982 , the fattening period (25 to $100 \mathrm{~kg}$ ) was shortened by 30 days (120) to 90 days), weight,

- the feed saving was about $50 \mathrm{~kg}$ per fattening pig between 25 and $100 \mathrm{~kg}$ live

-.- during this period, the backfat weight was reduced by $2 \mathrm{~kg}$ and the amount of loin increased by $2.5 \mathrm{~kg}$ in $80 \mathrm{~kg}$ carcasses.

Our results are similar to those obtained by OlLivier (1974) and Houlx et al. (1978) who estimated the genetic progress in the Large White breed in 1953-1966 and 1966-1973, respectively.

It is interesting to notice that the progress was large with regard to all the criteria corresponding to selection targets (average daily gain, food conversion ratio, body composition) and small for all the other criteria such as dressing percentage or carcass length.

Performance levels have not reached a plateau, but the yearly progress has been slowing down in the last few years.

\section{Theoretical efficiency of selection on prolificacy in pigs Possible modifications of the present index}

\author{
G. BOLET *, M. TARTAR *, D. LALOE **, C. FELGINES * \\ "I.N.R.A., Station de Génétique quantitative et appliquée, 78350 Jouy-en-Josas \\ **U.P.R.A. porcine, 95 bis, boulevard Pereire, 75017 Paris
}

France

The validity of the selection index of sows on prolificacy proposed to the farmers was examined on the basis of new estimations of two types of genetic parameters calculated on Large White and French Landrace pigs of U.P.R.A. herds.

- The genetic correlations between prolificacy of successive litters appeared to be different from 1. An "optimum" selection index taking into account these correlations was calculated according to a constant objective and compared with the present index. For the same genetic hypothesis, the accuracy and efficiency of the former were only a little higher than those of the latter; on the other hand, the underlaying hypothesis of the present index led to an overestimation of its accuracy, all the more marked as the number of litters in the index was high.

- The genetic correlations of prolificacy with growth and fattening performances were not all equal to zero; more particularly, they appeared to be unfavourable with backfat thickness, measured on young boars in testing stations. In this case, selection on these two groups of characters shoud not be considered independently, but rather on the basis of a combined index, especially for breeds used as a maternal line in crossbreeding schemes. 